\title{
Pemberdayaan Perempuan Dalam Produksi Masker Dan Penerapan Disiplin Memakai Masker Bagi Pekerja Harian Dalam Penanganan Wabah Covid-19
}

\author{
Wiwit Probowati*, Nosa Septiana Anindhita \\ Fakultas Sains dan Teknologi, Universitas 'Aisyiyah Yogyakarta \\ email:wiwitprobo@unisayogya.ac.id
}

\begin{abstract}
The Covid-19 outbreak that hit globally had amajor impact on economic activity in developing countries, especially Indonesia. In order to continue carrying out daily activities, especially working, it is necessary to comply with health protocol. Health protocols when doing activities include wearing masks, washing hands frequently with soap, avoiding crowds and maintaining a minumum distance of 1.5 meters from each other. The need for masks that are currentky not fulfilled by daily workers or laborers in Margomulyo village, Seyegan sub-district, Sleman regency, Province of Yogyakarta is primary need while working. The importance of education regarding the dangers of transmission of the Corona Virus or SARS-Cov-2 needs to be done to prevent the faster transmission of the virus. Therefore, the organization group 'Aisyiyah in collaboration with Universitas 'Aisyiyah Yogyakarta, empowers women tailors in neighborhood to produce cloth masks. Furthermore, these mask were distributed to daily workers in the Mrgomulyo village environment who had high mobility and had ahigh potential to transmit the Corona virus.
\end{abstract}

Keywords: Outbreak, Covid-19, health protocol, daily worker, cloth mask

\begin{abstract}
Abstrak
Wabah Covid-19 yang melanda secara global berdampak besar terhadap aktivitas perekonomian negara-negara berkembang terutama Indonesia. Agar dapat tetap melaksanakan aktivitas sehari-hari terutama bekerja diperlukan kepatuhan terhadap protokol kesehatan. Protokol kesehatan saat beraktivitas di luar antara lain memakai masker, sering mencuci tangan menggunakan sabun, menghindari kerumunan dan jaga jarak minimal 1.5 meter satu sama lain. Kebutuhan masker yang saat ini tidak dapat dipenuhi oleh pekerja harian atau buruh yang berada di desa Margomulyo, kecamatan Seyegan, kabupaten Sleman, Yogyakarta menjadi kebutuhan primer saat bekerja. Pentingnya edukasi mengenai bahaya transmisi Virus Corona atau (SARS-Cov-2) perlu dilakukan guna mencegah penyebaran virus yang semakin cepat. Oleh karena itu kelompok persyarikatan 'Aisyiyah kecamatan Seyegan bekerjasama dengan Universitas 'Aisyiyah Yogyakarta memberdayakan penjahit perempuan yang ada di lingkungan sekitar untuk memproduksi masker kain. Selanjutnya masker kain ini dibagikan untuk para pekerja harian di lingkungan desa Margomulyo yang mobilitasnya tinggi dan berpotensi tinggi menularkan virus Corona
\end{abstract}

Kata Kunci: wabah, Covid-19, protokol kesehatan, pekerja harian, masker kain

\section{PENDAHULUAN}

Coronavirus merupakan salah satu virus yang menyebabkan sakit pada hewan dan manusia. Pada manusia, beberapa virus Corona diketahui dapat menyebabkan gejala demam sampai infeksi saluran pernafasan sama seperti penyakt Middle East Respiratory Syndrome (MERS) dan penyakit Severe Acute Respiratory Syndrome (SARS). Semenjak dinyatakan sebagai wabah nasional pada Desember 2019 di China, virus Corona yang telah bermutasi menjadi 
novel coronavirus (SARS-CoV-2) menjadikan transmisi penularannya menjadi lebih cepat dan massif ${ }^{1,2}$. Sehingga pada Maret 2020 Organisasi Kesehatan Dunia (WHO) menyatakan penyakit yang disebabkan oleh novel coronavirus yang disebut Coronavirus Desease (COVID-19) ini sebagai wabah global di seluruh dunia atau disebut pandemi ${ }^{3}$.

Infeksi SARS-CoV-2 umumnya menyebabkan penyakit pernapasan ringan hingga berat dan kematian, sedangkan sebagian orang yang terinfeksi virus ini tidak pernah menunjukkan gejala. Transmisi SARS-CoV-2 dapat melalui transmisi kontak langsung dengan penderita, melalui droplet (percikan), melaui udara (airborne), fomit, fekal-oral, melalui darah, ibu ke anak, dan binatang ke manusia ${ }^{4}$. Data awal dari Tiongkok mengindikasikan bahwa orang tanpa gejala dapat menyebarkan infeksi kepada orang lain. Untuk lebih memahami peran transmisi dari orang tanpa gejala, transmisi dari orang yang terinfeksi yang tidak pernah menunjukkan gejala (transmisi asimtomatik) dan transmisi dari orang yang terinfeksi tetapi belum menunjukkan gejala (transmisi prasimtomatik) perlu dibedakan. Pembedaan ini penting dalam pengembangan strategi-strategi kesehatan masyarakat untuk mengendalikan transmisi ${ }^{3}$.

Pada awal dinyakatan sebagai pandemi global pada bulan Maret 2020 pemerintah Indonesia mulai melakukan strategi untuk menghentikan penyebaran virus. Dimulai dari penutupan pintu-pintu masuk virus dari luar negeri, penutupan sekolah sampai pengaturan dan pembatasan aktivitas perekonomian secara langsung. Namun di Indonesia belum sampai diterapkan locdown. Teknologi deteksi COVID-19 pun terus ditingkatkan dalam hal jumlah dan kapasitas fasilitas laboratorium yang mampu dengan cepat dan akurat mendeteksi warga yang terkonfirmasi positif di Indonesia.
Terutama ketersediaan seperangkat alat alat untuk proses PCR (Polymerase Chain Reaction) yang dapat mendeteksi secara akurat adanya virus Corona dalam tubuh. Sehingga data persebaran virus ini dapat dianalisis secara epidemiologi dengan baik. Semakin hari jumlah penderita terkonfirmasi positif COVID-19 semakin bertambah dan belum ada tanda-tanda penurunan angka positif.

Pemberlakuan kerja di rumah bagi pekerja dan belajar di rumah bagi pelajar membuat roda perekonomian di Indonesia terpengaruh dan diperkirakan akan terjadi inflasi apabila tidak mampu beradaptasi dan berinovasi. Tidak sedikit juga perusahaan yang merumahkan karyawannya sehingga banyak masyarakat yang terdampak Covid-19 secara perekonomian. Sementara itu lapisan masyarakat yang juga terdampak adalah para pekerja harian yang mendapatkan upah atau penghasilan per hari untuk dapat bertahan hidup. Akibat Covid-19 ini mereka sementara tidak dapat bekerja ke luar baik pedagang asongan, pedagang kaki lima, buruh pasar, buruh bangunan dan buruh tani. Tidak semua jenis pekerjaan dapat dilakukan di rumah seperti himbauan Pemerintah. Oleh karena itu, untuk tetap menggerakkan roda perekonomian Pemerintah mensosialisasikan penerapan protokol kesehatan agar tetap beraktivitas.

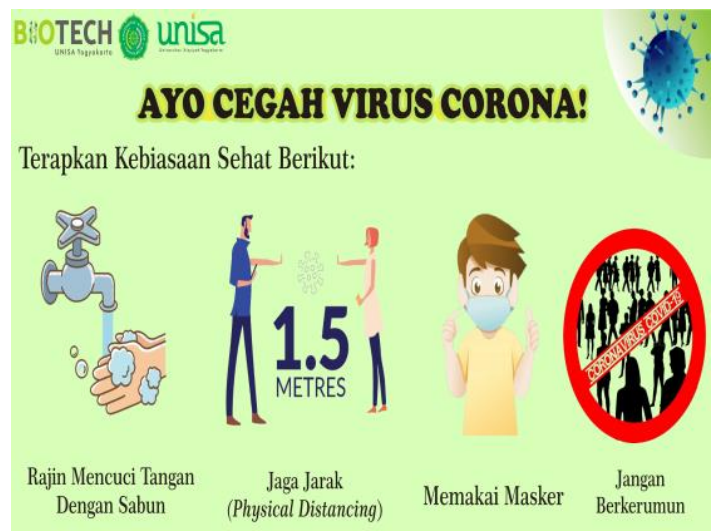

Gambar 1. Protokol Kesehatan Covid-19.

Protokol kesehatan tersebut berupa peraturan yang harus dipatuhi ketika keluar rumah seperti memakai masker, 
jaga jarak antar orang minimal 1.5 meter, menghindari kerumunan, sering mencuci tangan dengan sabun dan air mengalir, dan apabila daurat pakailah hand sanitizer yang mengandung alkohol. Apabila tidak ada kepentingan yang mendesak diusahakan beraktivitas di dalam rumah saja. Kemudian untuk menjaga kesehatan dan meningkatkan daya tahan tubuh makanlah makanan berizi dan perbanyak konsumsi buah dan sayur. Bagi pekerja harian yang harus keluar rumah setiap hari dan memiliki mobilitas tinggi, masker merupakan kebutuhan utama untuk menghindari paparan virus Corona. Namun pentingnya masker untuk aktivitas sehari-hari bagi para pekerja harian masih perlu disosialisasikan dan ditegaskan. Oleh karena itu kelompok persyarikatan Muhammadiyah melalui Pimpinan Cabang 'Aisyiyah di Kecamatan Seyegan Kabupaten Sleman menggalakkan program pemenuhan kebutuhan masker dengan memberdayakan perempuan untuk membuat masker. Sasaran utama sosialisasi wajib memakai masker dan pembagian masker adalah untuk para pekerja harian yang mana mereka belum tanggap terhadap wabah Covid-19 ini dan belum paham mengenai bahaya terinfeksi virus SARS-Cov-2

\section{METODE PENGABDIAN}

Metode pelaksanaan kegiatan IPTEKS bagi masyarakat mengenai "Pemberdayaan Perempuan dalam Produksi dan Penerapan Pemakaian Masker bagi Pekerja Harian dalam Pencegahan Penularan Wabah Covid-19" sebagai berikut:

1. Persiapan

Pada tahap ini, kegiatan yang dilakukan yaitu mengurus perizinan dalam melakukan pengabdian masyarakat, melakukan konsolidasi dengan sasaran, serta penyusunan materi dan persiapan alat bahan untuk kegiatan.
a. Perizinan

Perizinan dalam hal ini berkenaan dengan kesediaan mitra, yaitu masyarakat desa Margomulyo, untuk dijadikan tempat pelaksanaan IPTEKS pengabdian masyarakat tentang Pemberdayaan Perempuan dalam Produksi dan Penerapan Pemakaian Masker bagi Pekerja Harian dalam Pencegahan Penularan Wabah Covid19.

b. Konsolidasi dengan sasaran

Konsolidasi dengan sasaran, dalam hal ini kepala desa Margomulyo, sangat diperlukan untuk memperkuat hubungan mitra kerjasama yang telah terwujud melalui perizinan. Konsolidasi mencakup pengamatan kondisi di lapangan dan melakukan diskusi dengan perangkat desa dan tokoh masyarakat mengenai kebutuhan masker bagi pekerja harian di desa margomulyo. Konsolidasi dilakukan melalui media komunikasi Whatsapp guna menghindari pertemuan fisik dalam jumlah banyak. Karena adanya kerumunan orang lebih dari 10 orang sangat rentan untuk terjadinya penularan virus. Konsolidasi juga dilakukan dengan kelompok penjahit perempuan yang ada di wilayah kecamatan Seyegan.

c. Penyusunan materi

Berdasarkan hasil konsolidasi dengan pihak perangkat desa dan tokoh masyarakat Margomulyo, berbagai materi yang akan digunakan untuk mendukung pelaksanaan dikumpulkan.

d. Persiapan alat bahan

Persiapan berbagai alat bahan yang mendukung pelaksanaan

Pemberdayaan Perempuan dalam Produksi dan Penerapan Pemakaian Masker bagi Pekerja Harian dalam Pencegahan Penularan Wabah Covid19.

Ada beberapa tahap dalam pelaksanaan pengabdian masyarakat ini adalah. 
1) Pendataan warga yang tercatat sebagai warga dengan pekerjaan sehari-hari sebagai buruh ataupun pekerja harian yang membutuhkan masker.

2) Pembelian kain dan bahan untuk pembuatan masker kain.

3) Penyerahan bahan untuk pembuatan masker kepada beberapa penjahit yang ada di wilayah desa Margomulyo

4) Proses penjahitan dilakukan selama dua minggu dengan jumlah masker sesuai dengan data warga yang akan mendapatkan.

5) Koordinasi dengan kepala dusun untuk mengumpulkan ketua RT sebagai perwakilan dalam sodialisasi kewaspadaan virus Corona dan penyerahan masker untuk warga.

6) Pembagian masker bagi pekerja harian di desa Margomulyo melalui kepala dusun dan perwakilan ketua RT.

7) Pembagian masker kepada pekerja harian yang diserahkan langsung oleh ketua RT.

\section{HASIL DAN PEMBAHASAN}

Wabah virus Corona jenis baru (SARS-Cov-2) yang bermula merebak di kota Wuhan, Republik Rakyat Tiongkok akhir tahun 2019 menyebar di seluruh negara dan ditetapkan sebagai wabah global (pandemi). Wabah virus Corona atau yang disebut Covid-19 ini mulai masuk Indonesia sekitar bulan Februari 2020. Berbagai kasus positif terus terdeteksi sehingga menambah data adanya Covid-19 di Indonesia. Secara epidemiologis data kasus positif setiap hari tidak ideal karena sejak awal terkena wabah pemerintah belum siap dalam hal infrastruktur laboratorium molekuler yang dapat mendeteksi secara akurat terjadinya infeksi virus tersebut. Sehingga dalam situasi wabah virus baru tersebut pemerintah dipaksa bergerak cepat, tanggap dan penuh kehati-hatian dalam mengendalikan penyebaran virus.

Pemberlakuan kerja di rumah bagi pekerja dan belajar di rumah bagi pelajar membuat roda perekonomian di Indonesia terpengaruh dan diperkirakan akan terjadi inflasi apabila tidak mampu beradaptasi dan berinovasi. Golongan masyarakat yang paling terdampak selain karyawan perusahaan yang dirumahkan adalah pekerja harian yang kehilangan pekerjaannya ataupun tidak mendapat akses untuk bekerja. Pekerja harian seperti tukang batu atau buruh bangunan sementara mengalami penundaan kerja karena aktivitas pembangunan terhenti. Sementara pedangan asongan yang biasa keliling desa, keliling pasar juga mengalami penurunan omset. Bagaimana tidak, masyarakat yang umumnya takut untuk keluar rumah juga lebih waspada berinteraksi dengan orang yang mempunyai mobilitas tinggi dan berinteraksi dengan banyak orang. Apalagi orang yang tidak paham dan waspada terhadap terjadinya transmisi virus Corona pasti abai akan protokol kesehatan.

Dalam rangka edukasi tentang kewaspadaan terhadap infeksi penyakit yang disebabkan virus Corona Covid-19, Prodi Bioteknologi Universitas 'Aisyiyah Yogyakarta menyasar para pekerja harian di desa Margomulyo, kecamatan Seyegan, kabupaten Sleman Yogyakarta. Pekerja harian yang terdata di pusat infomasi kependudukan kantor keluarahan menyebutkan bahwa pekerja harian di desa Margomulyo beraneka ragam antara lain penjual makanan keliling, pengrajin bamboo yang menggunakan sepeda ke pasar menjajakan hasil kerajinan dan buruh bangunan. Pekerja harian seperti ini sangat potensial mentransmisikan virus apabila protokol kesehatan tidak dijalankan. Pada acara pengabdian masyarakat ini melalui penyuluhan terbatas perwakilan ketua RT, selebaran leaflet tentang Covid-19, dan pembagian masker kain hasil pemberdayaan perempuan ini dapat tersalurkan. 


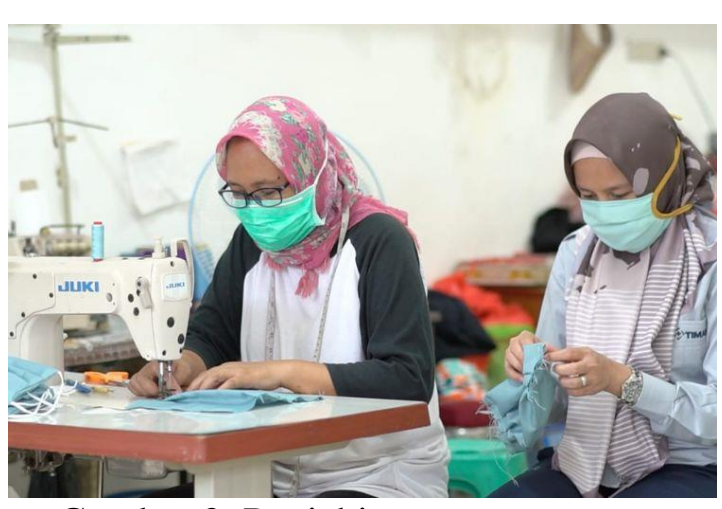

Gambar 2. Penjahit perempuan yang sedang menjahit masker kain

Protokol kesehatan tersebut berupa peraturan yang harus dipatuhi ketika keluar rumah seperti memakai masker, jaga jarak antar orang minimal 1.5 meter, menghindari kerumunan, sering mencuci tangan dengan sabun dan air mengalir, dan apabila daurat pakailah hand sanitizer yang mengandung alkohol 5. Apabila tidak ada kepentingan yang mendesak diusahakan beraktivitas di dalam rumah saja. Kemudian untuk menjaga kesehatan dan meningkatkan daya tahan tubuh makanlah makanan berizi dan perbanyak konsumsi buah dan sayur. Bagi pekerja harian yang harus keluar rumah setiap hari dan memiliki mobilitas tinggi, masker merupakan kebutuhan utama untuk menghindari paparan virus Corona. Namun pentingnya masker untuk aktivitas sehari-hari bagi para pekerja harian masih perlu disosialisasikan dan ditegaskan. Oleh karena itu UNISA bersama kelompok persyarikatan Muhammadiyah melalui Pimpinan Cabang 'Aisyiyah di Kecamatan Seyegan Kabupaten Sleman mengadakan program pemenuhan kebutuhan masker dengan memberdayakan perempuan untuk membuat masker. Sasaran utama sosialisasi wajib memakai masker dan pembagian masker adalah untuk para pekerja harian yang mana mereka belum tanggap terhadap wabah Covid-19 ini dan belum paham mengenai transmisi virus SARS-Cov-2.

Proses pembuatan masker kain dilakukan di rumah masing-masing penjahit yang tersebar di wilayah desa Margomulyo. Masker kain berlapis dinilai dapat menyaring partikel debu dan bakteri selain itu penambahan bahan spunbond sebagai pelapis dapat menghambat transmisi virus masuk ke tubuh melalui rongga pernapasan. Hal ini diperkuat dengan penelitian Fischer et. al (2020) yang menyatakan bahwa masker kain berlapis bahan spunbond dapat dijadikan alternatif paling murah untuk dijadikan masker dan efektif menghambat masuknya virus ke tubuh.

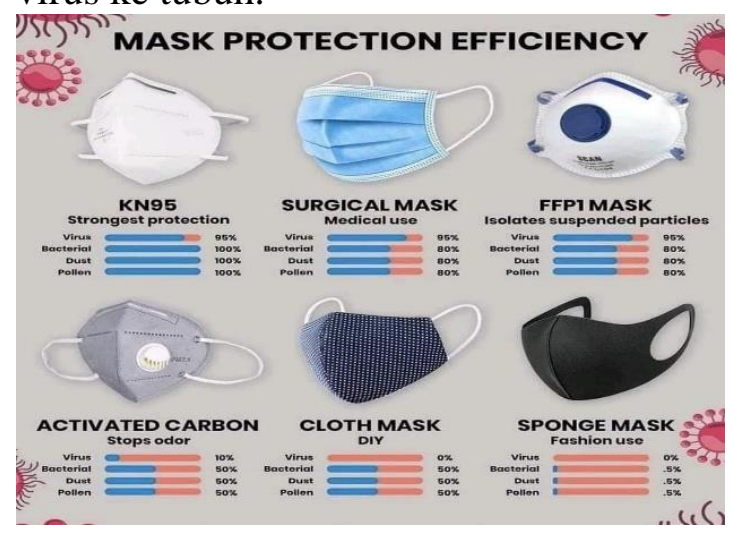

Gambar 3. Efisiensi berbagai jenis masker

Dari percobaan uji 14 jenis masker kain, penambahan lapisan bahan spunbond mampu menghambat masuknya droplet berisi virus masuk ke tubuh. Jenis masker yang paling kuat dalam memproteksi masuknya virus adalah masker KN95 karena terbukti mampu menghambat masuknya virus sebesar $95 \%$, sedangkan masker bedah (medis) juga sangat kuat untuk menghambat masuknya virus ke tubuh ${ }^{7}$. Namun pemakaian masker KN95 dan masker medis pad aktivitas sehari-hari di luar rumah tidak disarankan, karena selain harganya sangat mahal juga penggunaannya sekali pakai ${ }^{8}$. Menurut Kementerian Kesehatan Republik Indonesia ${ }^{9}$, masker medis yang digunakan sekali pakai kemudian harus dibuang dapat menyebabkan sampah dan masih dapat menularkan virus. Penggunaan masker medis untuk aktivitas sehari-hari sangat tepat. Masker kain berlapis efektif melindungi selama pemakaian 4 jam kemudian dapat dicuci kembali. 


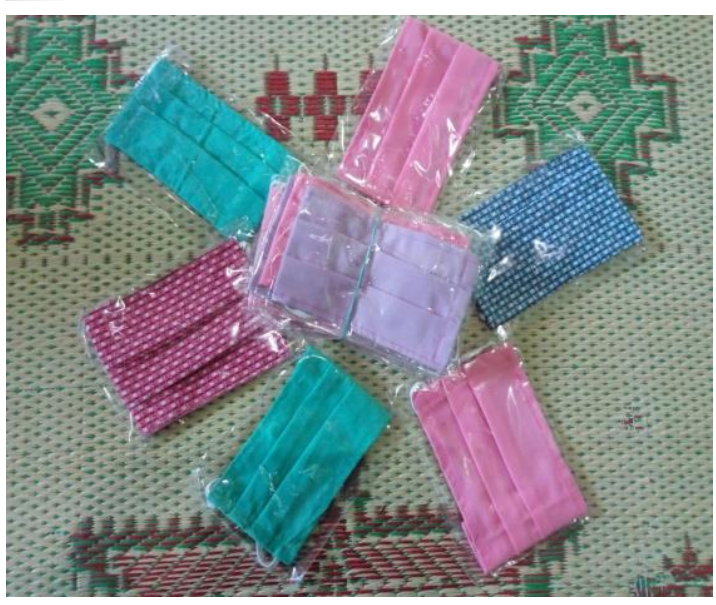

Gambar 4. Masker kain berlapis yang dibuat oleh penjahit desa Margomulyo

Masker kain yang telah selesai dibuat oleh beberapa penjahit desa Margomulyo ini segera dikumpulkan. Sosialisasi tentang pentingnya memakai masker disampaikan kepada masyarakat melalui kepala desa, ketua RW dan perwakilan ketua RT desa Margomulyo untuk membatasi acara perkumpulan yang melebihi 10 orang. Perkumpulan masa harus dibatasi jumlahnya agar tidak menimbulkan potensi berkerumun sehingga meningkatkan potensi transmisi virus. Protokol jaga jarak harus tetap dijalankan demi keselamatan dan keamanan semua.

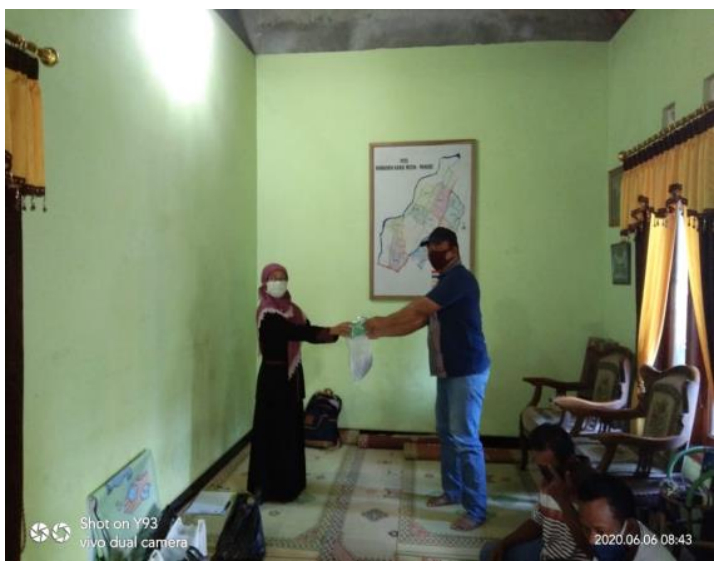

Gambar 5. Penyerahan masker secara simbolis kepada perwakilan ketua RW

Acara sosialisasi ini pun berlangsung singkat, padat dan jelas karena pada wabah Covid-19 ini aktivitas harus memperhatikan durasi pertemuan, ventilasi dan jarak. Tiga hal tersebut harus dipatuhi dan dijalankan agar terhindar dari paparan virus corona. Setelah acara sosialisasi maka dilanjutkan foto bersama perangkat desa yang nanti akan membantu menyampaikan info tentang virus Corona kepada warga secara langsung.

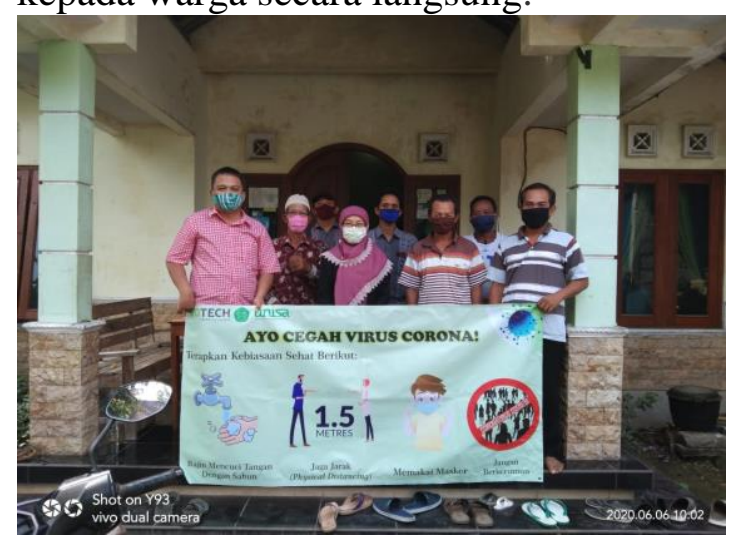

Gambar 6. Foto bersama setelah acara sosialisasi pemakaian masker

Masker kain hasil pemberdayaan perempuan yang telah diserahkan kepada perangkat desa kemudian disampaikan langsung kepada warga desa Margomulyo yang telah terdata. Masker kain yang disalurkan tepat sasaran karena warga yang terdata merupakan warga yang kurang mampu dan utamanya adalah pekerja harian yang setiap hari harus keliling dan berativitas.

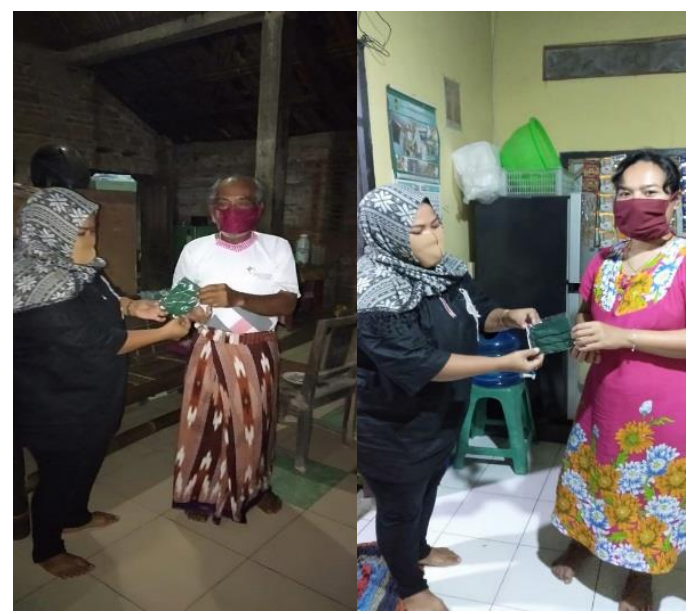

Gambar 7. Pemberian masker kepada pekerja harian warga desa Margomulyo.

Setiap orang mendapatkan 2 buah masker kain agar dapat digunakan seharihari karena dapat digunakan kembali 
setelah dicuci. Masyarakat sangat gembira dan terbantu mendapatkan pencerahan tentang virus Corona dan bantuan masker. Pada saat wabah Covid-19 melanda Indonesia kehidupan mereka bertambah sulit dengan aktivitas perekonomian yang terhambat. Ditambah kewajiban memakai masker di luar yang mana pada saat itu harga masker melambung tinggi sampai 10 kali lipat dari biasanya. Hal ini dikarenakan permintaan akan masker sangat tinggi namun belum diimbangi dengan stok produksi yang memenuhi permintaan.

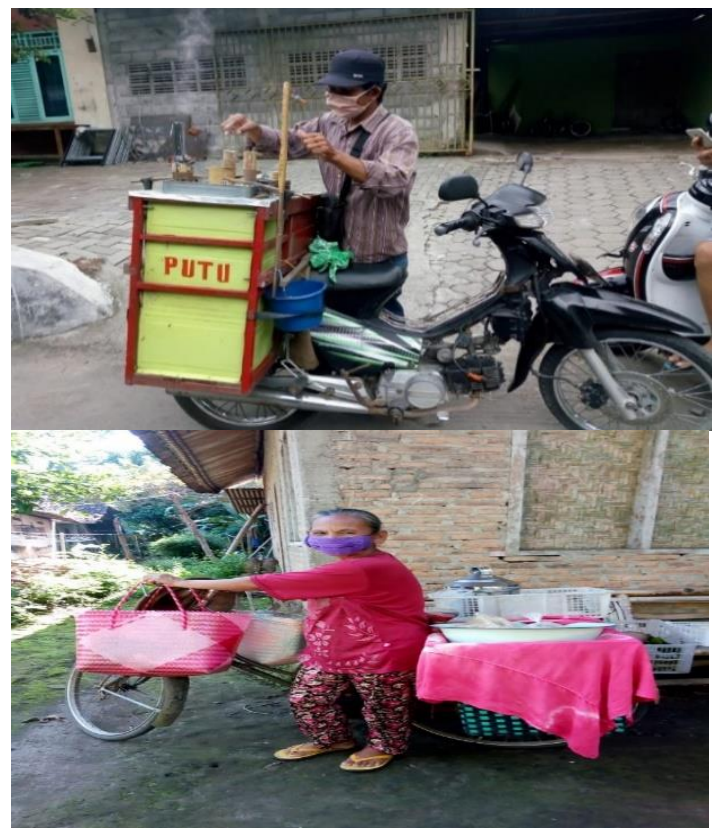

Gambar 8. Protret pedagang keliling yang telah memakai masker untuk aktivitas sehari-hari

\section{SIMPULAN}

Kelompok penjahit 'Aisyiyah mampu menjahit sejumlah masker kain untuk dibagikan kepada para pekerja harian di wilayah desa Margomulyo, Seyegan, Sleman.

Kebutuhan masker untuk para pekerja harian terpenuhi berkat adanya masker gratis yang selalu tersedia di kantor Pimpinan Cabang 'Aisyiyah Seyegan, Sleman Yogyakarta

\section{UCAPAN TERIMAKASIH}

Kami tim pengabdian Program Studi Bioteknologi mengucapkan terima kasih kepada Lembaga Penelitian dan Pengabdian kepada Masyarakat Universitas 'Aisyiyah Yogyakarta atas dukungannya melalui hibah internal pengabdian masyarakat tahun 2020. Kami juga berterima kasih kepada warga masyarakat desa Margomulyo atas kerjasamanya dan antusiasmenya.

\section{DAFTAR PUSTAKA}

[1] Zheng, Jun. Sars-Cov-2: an emerging Coronavirus that causes a global threat. International Journal of Biological Sciences, Vol.16 (10). pp.16781685.doi:7150/ijbs. 45053.(2020).

[2] Rothan, HA., Byrareddy SN. The epidemiology and pathogenesis of coronavirus disease (Covid-19) outbreak. J Autoimun. Published online

Maret.DOI:10.1016/j.jaut.2020.10 2433.

[3] WHO. 2019. Geneva, Switzerland, Novel Coronavirus (2019-nCov), Situation report https://www.who.int/docs/defaultsource/coronaviruse/situationreports/20200122-sitrep-2-2019ncov.pdf?sfvrsn $=4$ d5 bcbca 2 (Accessed on 28 Feb 2020).

[4] WHO. 2020. Transmisi SARSCov-2: implikasi terhadap kewaspadaan pencegahan infeksi. Pernyataan keilmuan. 9 Juli 2020.

[5] Susilo, A., C. Martin Rumende, Ceva W Pitoyo, Widayat Djoko Santoso, Mira Yulianti, Herikurniawan, Robert Sinto, Gurmeet Singh, Leonard Nainggolan, Erni J Nelwan, Lie Khie Chen, Alvina Widhani, Edwin Wijaya, Bramantya Wicaksana, Maradewi Maksum, Firda Annisa, Chyntia OM 
Jasirwan, Evy Yunihastuti.

Coronavirus disease 2019: tinjauan

literature terkini. Jurnal Penyakit

Dalam Indonesia. Vol.7, No.1, Maret 2020.

[6] Belkin, N.L. 1997. The evolution of the surgical mask: Filtering efficiency versus effectiveness. Infect. Control Hosp. Epidemiol. 18, 49-57 (1997).

Doi:10.2307/3014196Medline.

[7] Fischer, E.P, Martin C. Fischer, David Grass, Isaac Henrion, Warren S. Warren, and Eric Westman. Low-cost measurement of facemask efficacy for filtering expelled droplets during speech. Science Advances. August. 7 doi:10.1126/sciadv.abd3083.(202

$0)$.

[8] Liu J, Liao X, Qian S, Yuan J, Wang F, Liu Y. Community transmission on Severe Acute Respiratory Syndrome Coronavirus 2, Shenzhen, China. Emerg Infect Dis. 26 (3).2020.

[9] Kementerian Kesehatan Republik Indonesia. Info infeksi emerging kementerian kesehatan RI [Internet]. 2020. Update 30 Maret. https://infeksiemerging.kemkes.g o.id/. 